\title{
Pathophysiology of experimental Aeromonas hydrophila infection in mice
}

\author{
RITA A. BRENDEN* and H. W. HUIZINGA†
}

Department of Biological Sciences, Illinois State University, Normal, Illinois, USA 61761

\begin{abstract}
Summary. A virulent fish strain of Aeromonas hydrophila was inoculated intramuscularly into laboratory mice (B10.G strain). Histological, biochemical and haematological changes during the first $36 \mathrm{~h}$ of the infection were measured. Inoculation led to septicaemia, tissue damage, endotoxic shock and death. Histological examination revealed: (1) severe muscle necrosis at the injection site; (2) oedema, haemorrhage and neutrophil infiltration of the lung; and (3) focal parenchymal necrosis in the liver. Significant increases in aspartate aminotransferase, alanine aminotransferase, intestinal bilirubin and blood urea nitrogen were noted in blood and intestinal samples; decreased plasma glucose and haematological changes were also recorded. Ketones, increased protein, glucose, bilirubin and blood were detected in the urine. Endotoxaemia was demonstrated as early as $2 \mathrm{~h}$ after inoculation and persisted for more than $36 \mathrm{~h}$. The changes resembled those described for certain other experimental infections in laboratory animals. Our results suggest that endotoxin contributed to the pathogenesis of aeromonas infection in mice.
\end{abstract}

\section{Introduction}

Aeromonas hydrophila, a gram-negative bacillus, is commonly isolated from natural waters and from the organs of healthy and diseased fish (Shotts et al., 1972; Hazen et al., 1978). It has been found with increasing frequency as an opportunistic pathogen in human wounds sustained in aquatic environments (Deepe and Coonrod, 1980). These infections may remain localised and mild, or cause extensive muscle necrosis, or lead to septicaemia and infection in other sites. There may be skin lesions, fever, chills, and hypotension (Trust and Chipman, 1979). Furthermore, aeromonas infections frequently occur in immunocompromised hosts (Ketover et al. 1973; Sirinavin et al., 1984) and a mortality rate exceeding $50 \%$ has been reported in infected patients with neoplastic diseases (Ketover et al., 1973).

Natural and experimental aeromonas infections in fish, amphibia and reptiles are associated with haematological (Roberts, 1978) and histopathological changes (Huizinga et al., 1979). The pathogenesis of infections in poikilotherms and man are

* Present address: Department of Microbiology, Atran 509, The Mount Sinai Hospital, One Gustave L. Levy Place, New York, NY, USA 10029.

+ Requests for offprints should be sent to Dr H. Huizinga.

Received 21 May 1985; accepted 26 Jun. 1985. incompletely understood but may be associated with the release of toxins (Ketover et al., 1973). In vitro, $A$. hydrophila produces two haemolysins with different membrane-damaging effects on fibroblasts (Thelestam and Ljungh, 1981), and acyltransferase and phospholipase which deacylate human-erythrocyte membrane glycerophospholipids (MacIntyre and Buckley, 1978). The effects of $A$. hydrophila toxins produced in vitro have been studied in rats (Ljungh and Kronevi, 1982), rabbits (Wretlind et al., 1971) and mice (Rigney et al., 1978), but it is not known whether such toxins are elaborated in vivo.

Because aquatic environments are a frequent source of infection for man, we investigated pathophysiological changes in mice given intramuscular inocula of a virulent fish strain (AM3) of $A$. hydrophila. Most, but not all, of our observations were made $12-36 \mathrm{~h}$ after inoculation because $50 \%$ of the deaths that occurred took place during that period.

\section{Materials and methods}

\section{Bacterial strain}

A virulent strain (AM3) of $A$. hydrophila from a diseased fish was provided by D. H. Lewis, Texas A\&M University. Its virulence was maintained by occasional 
passage through goldfish, and the LD50 for mice was $4.5 \times 10^{6} \mathrm{cfu} /$ mouse (Brenden, 1984).

\section{Animals}

Inbred male B10.G mice aged 2-3 months and weighing $20-30 \mathrm{~g}$ were used. Two weeks earlier they had been treated for 3 days with $0.25 \%$ Panacure anthelminthic (Fenbendazole, Hoechst-Roussel Pharmaceuticals, Inc., Sommerville, NJ).

\section{Preparation of bacterial suspensions}

An 18-h culture of strain AM3 on sheep-blood agar (Difco) was subcultured in $3 \mathrm{ml}$ of Brain Heart Infusion (BHI) Broth (Difco) for $18 \mathrm{~h}$ at $37^{\circ} \mathrm{C}$. The culture was centrifuged and the pelleted cells were resuspended in phosphate buffered saline (PBS) to $40 \%$ transmittance at $435 \mathrm{~nm}$ (Spectronic 20 Spectrophotometer, Bausch and Lomb). Viable counts made in triplicate on BHI agar showed that such suspensions contained c. $3 \times 10^{8} \mathrm{cfu} / \mathrm{ml}$.

\section{Animal inoculation}

The bacterial suspension $\left(0 \cdot 1 \mathrm{ml} ; 3 \times 10^{7} \mathrm{cfu}\right)$ was injected intramuscularly in the left hindquarter of each test mouse. This inoculum produced $75 \%$ mortality within 6 days $(144 \mathrm{~h})$ and $50 \%$ mortality within $36 \mathrm{~h}$ (Brenden, 1984). Histological, biochemical, urinological, haematological and toxicological (endotoxin) studies were made with groups of 126, 130, 100, 130 and 25 infected mice, respectively.

\section{Pathological examination}

A total of 126 mice were given injections of $A$. hydrophila. Four were killed by cervical dislocation each hour for the first $11 \mathrm{~h}$. Six were killed at 12,24 and $36 \mathrm{~h}$. Control mice given $0 \cdot 1 \mathrm{ml}$ of PBS were also killed on each occasion. Gross pathological changes, body weight and spleen weight were recorded. Samples of spleen, lung, liver, kidney and duodenum, and muscle from the injection site were then removed and fixed in $10 \%$ neutral buffered formalin for $24 \mathrm{~h}$, embedded in paraffin and sectioned at 5-7 $\mu \mathrm{m}$. Sections were stained with haematoxylin and eosin, and by the McManus method for glycogen (Luna, 1968), the Gomori method for iron (Luna, 1968), and Taylor's modification of Gram's method (Bartholomew, 1980). Additional tissue samples were collected from survivors killed on day $6(144 \mathrm{~h})$ and immediately after death from those that succumbed to infection.

\section{Biochemical examination}

One hundred and thirty mice received injections of $A$. hydrophila, 80 received $0.1 \mathrm{ml}$ of PBS, and 45 remained untreated. Three infected mice were killed each hour for the first $11 \mathrm{~h}$ and 15-20 mice at 12, 24 and $36 \mathrm{~h}$. PBS- treated control mice were sampled at 12, 24 and $36 \mathrm{~h}$. Untreated mice were sampled at the beginning of the experiment (" $0 \mathrm{~h}$ ").

Mice were given an intraperitoneal $0 \cdot 1-\mathrm{ml}$ injection of ammonium heparin (100 units) $10 \mathrm{~min}$ before slaughter. The major blood vessels in the opened thorax were severed and blood was collected from the thoracic cavity with a syringe. The plasma was separated and frozen at $0^{\circ} \mathrm{C}$. The abdominal cavity was also opened and a length of small intestine measuring $7 \mathrm{~cm}$ from the pyloric sphincter was excised and the contents were expressed into $2 \mathrm{ml}$ of PBS. The intestinal samples were placed in a light-tight container and refrigerated $\left(4^{\circ} \mathrm{C}\right)$ overnight.

Plasma samples were diluted 1 in 10 in $0.9 \%$ saline for assay of aspartate aminotransferase (ASAT), alanine aminotransferase (ALAT), blood urea nitrogen (BUN) and glucose (GLU) on a KDA Analyzer (American Monitor Corp., Indianapolis, IN). Plasma was also analysed for sodium and potassium with a Model 143 Flame Photometer (Instrumentation Laboratory Inc., Boston, MA), and for total protein with a Refractometer (American Optical Co., Buffalo, NY). Undiluted intestinal contents were analysed for total and conjugated bilirubin with an ACA III Clinical Analyzer (Dupont Co., Wilmington, DE).

\section{Urine analysis}

One hundred mice were given $A$. hydrophila and groups of six were killed at 1-12, 24 and $36 \mathrm{~h}$. Forty-five PBStreated control animals were also killed, in groups of three on each occasion. Urine was collected by needle and syringe from the urinary bladder after death. The analysis included tests for protein, blood, ketones, glucose, bilirubin, urobilinogen and nitrite by means of $\mathrm{N}$-Multistix (Ames Chemical Co., Ames, IA). Visual colour and $p \mathrm{H}$ were recorded and specific gravity was measured with a refractometer.

\section{Haematological examination}

Fifteen mice received $0.1 \mathrm{ml}$ of ammonium heparin (100 units) intraperitoneally. Blood was then collected from the cut tail for the measurement of microhaematocrit (HCT) values and preparation of blood smears for white blood cell (WBC) differential counts. When, 2 days later, the same animals were given an injection of $A$. hydrophila, similar examinations were made from tail blood on single mice at hourly intervals from 1 to $11 \mathrm{~h}$.

Another 115 mice were given $A$. hydrophila and blood samples were collected from the tail of groups of $10-15$ at 12,24 and $36 \mathrm{~h}$. Sixty untreated mice were sampled at the beginning of the experiment (" $0 \mathrm{~h}$ ") to show the normal blood picture. Samples were collected from the tails of sixty further mice, which had received an injection of PBS, in groups of 20 at 12,24 and $36 \mathrm{~h}$. Mice received $0 \cdot 1$ $\mathrm{ml}$ of ammonium heparin (100 units) intraperitoneally before blood collection. Infected animals surviving beyond $36 \mathrm{~h}$ were sampled from the tail at $48,60,72$ and $144 \mathrm{~h}, 2-8$ mice being examined on each occasion. Blood 
collected at 12-144 h was examined for total red blood cell (RBC) and WBC counts, haemoglobin (HGB), HCT values, and differential WBC count. Blood to be examined for RBC and WBC counts and HGB was collected from the tail of each mouse into two 10- $\mu$ l capillary tubes. The content of each capillary tube was expelled into a tube containing $10 \mathrm{ml}$ of PBS $(0.9 \%)$. The diluted blood was examined with a Coulter Counter S Sr (Coulter Electronics Inc., Hialeah, FL). The Coulter data for WBC, RBC, and HGB were multiplied by five to compensate for a five-fold difference in dilution factors required for Coulter analysis of mouse blood over that required for human blood ( 1 in 1000 dilution of mouse blood versus 1 in 200 dilution of human blood). A hospital Coulter Counter S Sr was employed in this study and the upper and lower limits of analysis were therefore based upon human RBC concentrations. Mouse blood, having a higher concentration of RBCs (Altman and Dittmer, 1974), required a greater initial dilution before analysis on the Coulter Counter. The average WBC, RBC and $H G B$ values of two dilution tubes were recorded and analysed statistically. Blood intended for HCT determinations was collected into heparinised capillary tubes, which were then sealed with clay and centrifuged for 3 $\min$ at $13460 \mathrm{~g}$ in an IEC MB Microhaematocrit Centrifuge (International Equipment Co., Needham Heights, MA). Blood smears were stained by the WrightGiemsa method for differential white blood cell counts.

\section{Limulus amoebocyte lysate test}

Twenty-five mice were given $A$. hydrophila and 15 received PBS. One mouse/h $(1-12,24$ and $36 \mathrm{~h})$ from each group was given $0 \cdot 1 \mathrm{ml}$ of ammonium heparin ( 100 units) intraperitoneally, anaesthetised (sodium pentobarbital; Fort Dodge Laboratories, Fort Dodge, IA), and bled by cardiac puncture. The plasma was treated with chloroform as specified by Sigma Technical Bulletin (Sigma Chemical Co., St Louis, MO) for use in the E-toxate Test.

\section{Statistics}

The $t$-test was used to analyse spleen weights. A twoway analysis of variance (ANOVA) was used to analyse biochemical and haematological data. When no significant differences between untreated (control) and PBStreated (control) mice appeared, these uninfected animals were regarded as comprising a single control group. Data showing statistical differences $(p<0.05)$ by ANOVA were analysed with the Newman Keul's test (Kirk, 1968) to locate the treatment effects.

\section{Results}

\section{Clinical and pathological changes}

Clinical signs. Two hours after infection, all mice exhibited huddling, raised fur, and shaking, and, as death approached, laboured breathing and diarr- hoea. Ocular discharge and occasionally opacity were observed.

Gross pathology. Severe haemorrhage and swelling were observed within $24 \mathrm{~h}$ at the site of injection. By $144 \mathrm{~h}$ the lesion covered an area of $15-20 \mathrm{~mm}^{2}$, with necrosis extending into the musculature.

Experimental mice necropsied at 12, 24 and $36 \mathrm{~h}$ revealed congestion of the liver, spleen and kidney, and the heart was enlarged and dark in colour. There was a bright orange discolouration of the intestinal tract. Spleens from infected animals killed at $144 \mathrm{~h}(0.337 \pm 0.13 \mathrm{~g})$ were significantly larger $(p<0.05)$ than those of control animals $(0.043 \pm 0.04 \mathrm{~g})$.

Histopathology. All organs examined were congested, and the injection site showed severe necrosis of skin and muscle. Pulmonary congestion and WBC infiltration were noted as early as $1 \mathrm{~h}$ after inoculation. Liver pathology was variable. Congestion, swollen Kupffer cells and enlarged hepatocytes represented mild changes observed as early as $8 \mathrm{~h}$ after infection, and focal necrosis was seen later (24 and $36 \mathrm{~h}$ ). There was no depletion of glycogen but iron was present in all samples taken from 8-36 h.

At $2 \mathrm{~h}$ the spleen was congested, and loss of definition of the red and white pulp and an increase in the number of megakaryocytes were observed at $24 \mathrm{~h}$. Iron was present in samples taken at 8-36 h.

The kidneys and small intestine showed tissue oedema. Gram's stain failed to reveal bacteria in any tissue, but bacteria were cultured from all internal organs.

\section{Biochemical changes}

Glucose analysis. The plasma glucose values fluctuated but they were significantly lower $(p<0.0001)$ than those of the controls at 12 and $24 \mathrm{~h}$ (table I).

$A S A T$ and $A L A T$ analysis. Plasma ASAT values rose steadily in infected mice, significant differences $(p<0.0001)$ from controls being recorded at 11,12 , 24 and $36 \mathrm{~h}$. Plasma ALAT values fluctuated but were significantly elevated $(\mathrm{p}<0.0001)$ at 12 and $24 \mathrm{~h}$. The surviving animals sampled at $144 \mathrm{~h}$ had ASAT and ALAT values similar to those of the controls (table I).

$B U N$ analysis. BUN values were within one standard deviation from the mean of the control group for the first $10 \mathrm{~h}$ of the study and significantly raised $(p<0.0001)$ at $11,12,24$ and 36 h. Survivors had, at $144 \mathrm{~h}$, values similar to those of the controls (table I).

Intestinal bilirubin. Intestinal bilirubin concentrations were significantly raised $(p<0.0001)$ in all 
Table I. Biochemical analysis of plasma and intestinal contents from A. hydrophilainoculated mice

\begin{tabular}{|c|c|c|c|c|c|}
\hline \multirow[b]{2}{*}{$\begin{array}{l}\text { Hours } \\
\text { after } \\
\text { infection }\end{array}$} & \multicolumn{5}{|c|}{ Biochemical values (mean \pm SEM) } \\
\hline & $\begin{array}{c}\text { Plasma } \\
\text { GLU } \\
(\mathrm{mg} / \mathrm{dl})\end{array}$ & $\begin{array}{c}\text { Plasma } \\
\text { ASAT } \\
(\mathbf{u} / \mathrm{L})\end{array}$ & $\begin{array}{c}\text { Plasma } \\
\text { ALAT } \\
(\mathrm{u} / \mathrm{L})\end{array}$ & $\begin{array}{c}\text { Plasma } \\
\text { BUN } \\
(\mathrm{mg} / \mathrm{dl})\end{array}$ & $\begin{array}{c}\text { Intestinal } \\
\text { bilirubin } \\
\text { (mg/dl) }\end{array}$ \\
\hline $0+$ & $167 \cdot 5 \pm 5 \cdot 1$ & $429 \cdot 3 \pm 20 \cdot 7$ & $79 \cdot 3 \pm 2 \cdot 8$ & $28 \cdot 4 \pm 0.8$ & $0.52 \pm 0.03$ \\
\hline 1 & $* 246.7 \pm 19.4$ & $307 \cdot 0 \pm 90 \cdot 0$ & $104 \cdot 7 \pm 7 \cdot 7$ & $21 \cdot 3 \pm 7 \cdot 6$ & $0.48 \pm 0.06$ \\
\hline 2 & $188 \cdot 0 \pm 6 \cdot 4$ & $692 \cdot 0 \pm 292 \cdot 3$ & $148 \cdot 0 \pm 32 \cdot 2$ & $20 \cdot 0 \pm 2.0$ & $0.71 \pm 0.11$ \\
\hline 3 & $147 \cdot 3 \pm 27 \cdot 3$ & $741 \cdot 7 \pm 361 \cdot 4$ & $267 \cdot 3 \pm 113 \cdot 3$ & $18 \cdot 4 \pm 5.9$ & $0.61 \pm 0.12$ \\
\hline 4 & $183.0 \pm 45 \cdot 7$ & $550 \cdot 7 \pm 71 \cdot 3$ & $142 \cdot 3 \pm 6 \cdot 9$ & $24 \cdot 7 \pm 2 \cdot 9$ & $1 \cdot 08 \pm 0 \cdot 29$ \\
\hline 5 & $* 219.3 \pm 92.9$ & $522 \cdot 0 \pm 30 \cdot 0$ & $120 \cdot 3 \pm 12 \cdot 2$ & $22 \cdot 0 \pm 1 \cdot 0$ & $* 1.51 \pm 0.37$ \\
\hline 6 & $152 \cdot 0 \pm 17 \cdot 0$ & $607 \cdot 7 \pm 130 \cdot 0$ & $138.0 \pm 21.7$ & $29 \cdot 3 \pm 6 \cdot 7$ & $* 1.85 \pm 0.89$ \\
\hline 7 & $151 \cdot 7 \pm 20.9$ & $1020 \cdot 0 \pm 605 \cdot 7$ & $186 \cdot 3 \pm 79 \cdot 0$ & $18 \cdot 5 \pm 5 \cdot 5$ & $* 2.58 \pm 0.77$ \\
\hline 8 & $157 \cdot 3 \pm 25 \cdot 7$ & $944 \cdot 3 \pm 140 \cdot 6$ & $177 \cdot 0 \pm 16 \cdot 7$ & $26 \cdot 5 \pm 1 \cdot 5$ & $* 4.27 \pm 1.38$ \\
\hline 9 & $149 \cdot 3 \pm 14 \cdot 9$ & $1025 \cdot 0 \pm 92.9$ & $139 \cdot 7 \pm 17 \cdot 3$ & $22 \cdot 5 \pm 2 \cdot 5$ & $* 3.09 \pm 1.04$ \\
\hline 10 & $123 \cdot 3 \pm 24 \cdot 9$ & $949 \cdot 0 \pm 75 \cdot 5$ & $125 \cdot 7 \pm 12 \cdot 6$ & $21 \cdot 0 \pm 3 \cdot 0$ & $* 5.33 \pm 1.71$ \\
\hline 11 & $133 \cdot 7 \pm 21 \cdot 8$ & $* 1814.5 \pm 939.5$ & $157 \cdot 5 \pm 52 \cdot 5$ & $* 64.0 \pm 0.0$ & $* 4.21 \pm 0.73$ \\
\hline 12 & $* 107.2 \pm 9.9$ & $* 2416 \cdot 1 \pm 337.9$ & $* 327 \cdot 9 \pm 66 \cdot 1$ & $* 53.7 \pm 5.4$ & $* 3.03 \pm 0.59$ \\
\hline 24 & $* 81 \cdot 5 \pm 7 \cdot 5$ & $* 3407 \cdot 3 \pm 375.9$ & $* 338.9 \pm 39.7$ & $* 95 \cdot 0 \pm 5 \cdot 7$ & $* 5 \cdot 77 \pm 1.34$ \\
\hline 36 & $143 \cdot 2+8 \cdot 5$ & $* 1809.2 \pm 137.6$ & $200 \cdot 4 \pm 11.6$ & $* 66.7 \pm 5.7$ & $* 3.19 \pm 0.66$ \\
\hline 144 & $134 \cdot 2 \pm 12 \cdot 1$ & $321 \cdot 6 \pm 45 \cdot 4$ & $87 \cdot 7 \pm 6 \cdot 5$ & $19 \cdot 6 \pm 1.4$ & $0.69 \pm 0.08$ \\
\hline
\end{tabular}

GLU $=$ glucose; ASAT $=$ aspartate aminotransferase; ALAT $=$ alanine aminotransferase; BUN = blood urea nitrogen. $\mathrm{N}=3$ for samples taken at $1-11$ and $144 \mathrm{~h} ; \mathrm{N}=12-18$ for samples taken at $12-36 \mathrm{~h}$.

* Significantly different from the control group (see below) by ANOVA $(\mathrm{p}<0.0001)$ and Newman Keul's test $(\mathrm{p}<0.05)$.

$\dagger$ Control group (see Materials and Methods, Statistics); N=108-119.

samples taken from 5 to $36 \mathrm{~h}$. Survivors killed at $144 \mathrm{~h}$ had bilirubin values near to those of controls (table I).

Other biochemical parameters. Plasma sodium, potassium, and total protein concentrations did not differ significantly from those of the controls, provided that the plasma samples were obtained from unhaemolysed blood.

\section{Urine analysis}

Infected mice sampled at 5, 6, 10 and $11 \mathrm{~h}$ yielded insufficient urine for analysis; samples taken at 1,2, $3,4,7,8$ and 9 h had specific gravity, colour, $p \mathrm{H}$, protein, glucose, ketones and urobilinogen values similar to those of control mice, but bilirubin and blood were detected. At 12, 24 and $36 \mathrm{~h}$, urine from infected mice was abnormal in colour (yellow, green, or brown) and contained high concentrations of protein $(100-300 \mathrm{mg} \%)$. Of the 12 and $24 \mathrm{~h}$ urine samples, $50-100 \%$ gave positive tests for glucose, ketones, bilirubin and blood, whereas $0-56 \%$ were positive in $36 \mathrm{~h}$ samples.

\section{Haematological changes}

Infected mice showed slightly increased HCT values $(52-60 \% ; \mathrm{p}>0.05)$ between 2 and $8 \mathrm{~h}$ (table II), but by $24 \mathrm{~h}$ there was no difference from the control (pre-infection) values (mean 50.6\%). There was a significant decrease $(\mathrm{p}<0.001)$ thereafter. By day $6(144 \mathrm{~h})$, the $R B C$ values of infected mice were higher than at $72 \mathrm{~h}$ but significantly lower $(\mathrm{p}<0.001)$ than control values (table III). Visible haemolysis was present in some samples. Significantly reduced values $(p<0.001)$ for $R B C$ and $H G B$ were recorded at $36,48,60,72$ and $144 \mathrm{~h}$.

White blood cell counts measured at $12 \mathrm{~h}$ and later were higher than the control values, but significant differences $(\mathrm{p}<0.001)$ occurred only at 24 and $144 \mathrm{~h}$ (table III). Differential WBC counts showed a significant increase in polymorphonuclear leukocytes (PMN) and decrease in lymphocytes (LYM) in the 12, 24 and $36 \mathrm{~h}$ samples (table III). This shift towards a predominance of PMNs was observed as early as $5 \mathrm{~h}$ after infection (table II).

\section{Endotoxin assay}

Plasma from experimental mice sampled at 2-36 $\mathrm{h}$ after inoculation was positive for endotoxin by the amoebocyte lysate test. The gelation pattern for samples taken at 2-7 h was one of "starchy 
Table II. Haematological examination of mice $1-11 \mathrm{~h}$ after inoculation of $A$. hydrophila

\begin{tabular}{|c|c|c|c|c|c|c|c|c|c|c|c|}
\hline \multirow[b]{3}{*}{$\begin{array}{c}\text { Mouse } \\
\text { no. }\end{array}$} & \multirow{3}{*}{$\begin{array}{l}\text { Time (h) } \\
\text { after } \\
\text { infection } \\
\text { at which } \\
\text { post- } \\
\text { infection } \\
\text { samples } \\
\text { taken }\end{array}$} & \multicolumn{5}{|c|}{ Pre-infection values for } & \multicolumn{5}{|c|}{ Post-infection values for } \\
\hline & & \multirow{2}{*}{$\begin{array}{c}\mathrm{HCT} \\
(\%)\end{array}$} & \multicolumn{4}{|c|}{ WBC differential count } & \multirow{2}{*}{$\begin{array}{c}\text { HCT } \\
(\%)\end{array}$} & \multicolumn{4}{|c|}{ WBC differential count } \\
\hline & & & $\begin{array}{c}\text { PMN } \\
(\%)\end{array}$ & $\begin{array}{c}\text { LYM } \\
(\%)\end{array}$ & $\begin{array}{c}\text { MON } \\
(\%)\end{array}$ & $\begin{array}{c}\text { EOS } \\
(\%)\end{array}$ & & $\begin{array}{c}\text { PMN } \\
(\%)\end{array}$ & $\begin{array}{c}\text { LYM } \\
(\%)\end{array}$ & $\begin{array}{c}\text { MON } \\
(\%)\end{array}$ & $\begin{array}{c}\text { EOS } \\
(\%)\end{array}$ \\
\hline 1 & 1 & 54 & 5 & 95 & $\ldots$ & $\ldots$ & 48 & 27 & 64 & 9 & $\ldots$ \\
\hline 2 & 2 & 45 & 18 & 76 & 6 & $\ldots$ & 53 & 42 & 56 & 2 & $\ldots$ \\
\hline 3 & 3 & 52 & 10 & 90 & $\ldots$ & $\ldots$ & 57 & 39 & 54 & 5 & 2 \\
\hline 4 & 4 & 49 & 12 & 86 & 2 & $\ldots$ & 53 & 32 & 64 & 4 & $\ldots$ \\
\hline 5 & 5 & 48 & 18 & 80 & 2 & $\ldots$ & 53 & 52 & 44 & 4 & $\ldots$ \\
\hline 6 & 6 & 50 & 8 & 88 & 4 & $\ldots$ & 60 & 52 & 46 & $\ldots$ & 2 \\
\hline 7 & 7 & 50 & 18 & 79 & $\ldots$ & 3 & 59 & 62 & 34 & 4 & $\ldots$ \\
\hline 8 & 8 & 49 & 13 & 87 & $\ldots$ & $\ldots$ & 54 & 55 & 39 & 6 & $\ldots$ \\
\hline 9 & 9 & 50 & 24 & 76 & $\ldots$ & $\ldots$ & 52 & 50 & 44 & 6 & $\ldots$ \\
\hline 10 & 10 & 51 & 8 & 89 & 3 & $\ldots$ & 55 & 66 & 32 & 2 & $\ldots$ \\
\hline $1 I$ & 11 & 52 & 4 & 96 & $\ldots$ & $\ldots$ & 50 & 62 & 34 & 4 & $\ldots$ \\
\hline
\end{tabular}

HCT = microhaematocrit; WBC $=$ white blood cells; PMN = polymorphonuclear leukocyte, $L Y M=$ lymphocyte, $\mathrm{MON}=$ monocyte, $\mathrm{EOS}=$ eosinophil.

Table III. Haematological examination of mice 12-144 h after inoculation of $A$. hydrophila

\begin{tabular}{|c|c|c|c|c|c|c|c|c|}
\hline \multirow{3}{*}{$\begin{array}{l}\text { Time }(\mathrm{h}) \\
\text { after } \\
\text { inoculation }\end{array}$} & \multicolumn{8}{|c|}{ Haematological values (mean \pm SEM) } \\
\hline & \multirow[b]{2}{*}{$\begin{array}{c}\text { WBC } \\
\left(10^{3} / \mathrm{mm}^{3}\right)\end{array}$} & \multirow[b]{2}{*}{$\begin{array}{c}\mathrm{RBC} \\
\left(10^{6} / \mathrm{mm}^{3}\right)\end{array}$} & \multirow[b]{2}{*}{$\begin{array}{l}\text { HGB } \\
(\mathrm{mg} / \mathrm{dl})\end{array}$} & \multirow[b]{2}{*}{$\begin{array}{c}\mathrm{HCT} \\
(\%)\end{array}$} & \multicolumn{4}{|c|}{ WBC differential count } \\
\hline & & & & & $\begin{array}{c}\text { PMN } \\
(\%)\end{array}$ & $\begin{array}{c}\text { LYM } \\
(\%)\end{array}$ & $\begin{array}{c}\text { MON } \\
(\%)\end{array}$ & $\begin{array}{c}\text { EOS } \\
(\%)\end{array}$ \\
\hline $0 \dagger$ & $14 \cdot 5 \pm 0 \cdot 3$ & $11 \cdot 3 \pm 0 \cdot 1$ & $18 \cdot 6 \pm 0 \cdot 1$ & $50 \cdot 6 \pm 0 \cdot 2$ & $14 \cdot 8 \pm 2 \cdot 1$ & $83 \cdot 0 \pm 2 \cdot 6$ & $2 \cdot 0 \pm 0 \cdot 5$ & $0 \cdot 2$ \\
\hline 12 & $23 \cdot 4 \pm 1 \cdot 8$ & $10.4 \pm 0.4$ & $19 \cdot 5 \pm 0.4$ & $51 \cdot 8 \pm 1 \cdot 2$ & $* 73 \cdot 0 \pm 1 \cdot 4$ & $* 16 \cdot 0 \pm 2 \cdot 4$ & $11 \cdot 0 \pm 2 \cdot 2$ & 0.0 \\
\hline 24 & $* 26 \cdot 7 \pm 3 \cdot 3$ & $10 \cdot 4 \pm 0.4$ & $18.9 \pm 0.4$ & $50 \cdot 7 \pm 1 \cdot 4$ & $* 70 \cdot 0 \pm 4 \cdot 0$ & $* 16 \cdot 0 \pm 1 \cdot 0$ & $13 \cdot 0 \pm 2 \cdot 0$ & $1 \cdot 0$ \\
\hline 36 & $23 \cdot 5 \pm 1.9$ & $* 8 \cdot 5 \pm 0.4$ & $* 15 \cdot 5 \pm 0 \cdot 4$ & $* 42 \cdot 1 \pm 1 \cdot 0$ & $* 65 \cdot 0 \pm 7 \cdot 8$ & $* 30 \cdot 0 \pm 8 \cdot 2$ & $5 \cdot 0 \pm 0 \cdot 8$ & $0 \cdot 0$ \\
\hline 48 & $16 \cdot 9 \pm 1 \cdot 5$ & $* 8 \cdot 3 \pm 0 \cdot 3$ & $* 14.2 \pm 0.5$ & $* 35.4 \pm 1.8$ & $\ldots$ & $\ldots$ & $\ldots$ & $\ldots$ \\
\hline 60 & $18 \cdot 7 \pm 1.6$ & $* 7.7 \pm 0.2$ & ${ }^{*} 13.9 \pm 0.4$ & $* 35.0 \pm 1.0$ & $\ldots$ & $\ldots$ & $\ldots$ & $\ldots$ \\
\hline 72 & $23 \cdot 8 \pm 2 \cdot 5$ & $* 7 \cdot 0 \pm 0.4$ & $* 13.5 \pm 0.5$ & $* 33 \cdot 5 \pm 4 \cdot 5$ & $\ldots$ & $\ldots$ & $\ldots$ & $\ldots$ \\
\hline 144 & $* 44 \cdot 0 \pm 1 \cdot 2$ & $* 8.4 \pm 0.4$ & $* 15.6 \pm 0.5$ & $* 43.3 \pm 1 \cdot 8$ & $\ldots$ & $\ldots$ & $\ldots$ & $\ldots$ \\
\hline
\end{tabular}

See footnotes to table II.

$\mathrm{HGB}=$ haemoglobin .

$\mathrm{N}=8-14$ for samples taken at $12-48 \mathrm{~h} ; \mathrm{N}=2-4$ for samples taken at $60-144 \mathrm{~h}$.

* Significantly different from the control group by ANOVA $(p<0.001)$ and Newman Keul's test $(p<0.05)$.

† Control group: $\mathrm{N}=13$ for PMN, LYM, MON and EOS; $\mathrm{N}=112-116$ for WBC, RBC, HGB, and HCT.

granules" (+ reaction); a "soft gel" $(++$ reaction) was formed by the 8-36-h samples.

\section{Discussion}

A. hydrophila infection in mice caused extensive necrosis at the site of intramuscular inoculation, followed by septicaemia, endotoxic shock and death (Brenden, 1984). Hypotension, chills and fever are associated with septic shock in man (Trust and Chipman, 1979; Hardaway, 1980) and animals (Kabir et al., 1978). Conjunctivitis has been reported in $A$. hydrophila septicaemia in man (Feaster et al., 1978; Ramsay et al., 1978). 
Histopathological effects were mainly confined to the lungs and liver, but all organs showed signs of congestion. Corrin (1980) observed that the lungs of human bacterial-shock victims are the most frequently damaged organs. The liver of infected mice showed focal parenchymal necrosis and swelling of Kupffer cells, both of which can be caused by bacterial endotoxin (Levy and Ruebner, 1967). Filkins (1969) suggested that long and severe endotoxaemia impairs liver function by damaging the vasculature. However, parenchymal damage may also be caused by tissue anoxia resulting from vasoconstriction or by extracellular bacterial toxin.

Periodic hyperglycaemia occurred 1-6 h after infection, and was followed by a period of declining plasma glucose concentrations. The lowest mean glucose concentration of $81.5 \mathrm{mg} / \mathrm{dl}$ was reached in $24 \mathrm{~h}$, but glycogen stores in the liver were not depleted. Shands et al. (1969) reported glucose concentrations of $78 \mathrm{mg} / \mathrm{dl}$ at the time of death in endotoxin-treated mice.

The liver enzymes ASAT and ALAT increased, beginning at $2 \mathrm{~h}$ and reaching their maxima at $24 \mathrm{~h}$. The ASAT and ALAT increases may have been due to changes in cell membrane permeability during the first $11 \mathrm{~h}$. The high concentrations recorded at $11,12,24$ and $36 \mathrm{~h}$ may reflect the release of enzymes from tissue damaged by anoxia. Focal necrosis was observed in liver as early as $8 \mathrm{~h}$.

BUN concentrations rose significantly from 11 to $24 \mathrm{~h}$ and began to decline at $36 \mathrm{~h}$. Increased BUN levels suggest suppressed kidney function. Retention of urea without obvious kidney damage has been reported by Berry and Smythe (1961) in endotoxin-treated mice, and by Walker and Chesbro (1975) in mice infected with Klebsiella pneumoniae. The lack of urine production at $5,6,10$, and $11 \mathrm{~h}$ suggested reduced filtering ability of the kidney. Renal tissue was observed to be oedematous and congested in histological sections. Oedema alters the membrane permeability and would account for the increased excretion of protein in the urine. The presence of blood in some urine samples indicated haemorrhage.

Increased intestinal bilirubin concentrations, recorded from 5 to $36 \mathrm{~h}$, reached their maxima at $24 \mathrm{~h}$. Eddington and Kampschmidt (1968) noted a doubling of the bilirubin production in rats treated with endotoxin. They attributed this to lysis of RBCs or skeletal muscle cells, or to cytochromes or catalase. In the present study, the elevated bilirubin concentrations (intestinal and urinary), positive iron stains in liver and spleen, and decreased $R B C$, HGB and HCT suggest RBC lysis.

Total sodium and protein concentrations changed little. The only increases in potassium concentrations that occurred were attributed to the lysis of RBCs. Hambleton et al. (1977) reported no changes in sodium or potassium in rabbits infected with Francisella tularensis.

Oedema at the injection site, biochemical changes, and haemoconcentration 2-8 h after inoculation suggested an increase in vascular permeability caused by a toxin. Oedema and haemoconcentration have been reported in mice infected with Vibrio vulnificus (Bowdre et al., 1981).

Haemolysis of RBCs occurred in the period during which the majority of deaths occurred (24 $36 \mathrm{~h}$ ). In an account of fish infected with $A$. hydrophila Roberts (1978) reported blood-cell changes resembling those described here. Three mechanisms may account for RBC lysis: (1) activation of the alternate complement pathway by lipopolysaccharide; (2) increased phagocytosis of endotoxin-coated RBCs; and (3) the action of a haemolysin or other bacterial factor, such as phospholipase. RBCs damaged directly or indirectly would be removed from the circulation by the spleen. Iron deposits were present in spleen sections, and enlarged spleens were observed in surviving animals.

Endotoxaemia was present as early as $2 \mathrm{~h}$ after inoculation and persisted for at least $36 \mathrm{~h}$. Thus it coincided with the period during which most deaths occurred and was undoubtedly an important factor in the pathogenesis of the infection. Other bacterial products may also have been concerned. Thus Rigney et al. (1978) found that red leg disease of frogs was induced only when endotoxin and partially purified haemolysin of $A$. hydrophila were administered simultaneously. Further studies should concentrate on the effects of mutant strains of $A$. hydrophila deficient in certain extracellular toxins.

We thank the Department of Biological Sciences, Illinois State University and the Beta Lambda Chapter of the Phi Sigma Society for financial support; Dr P. Millikin, Proctor Community Hospital, Peoria, IL for his assistance in interpretation of the histological sections; and Mr L. Bulgrin and the laboratory of Pekin Memorial Hospital, Pekin, IL for allowing us access to their analytical equipment. 


\section{REFERENCES}

Altman P L, Dittmer D S 1974 Biology data book. 2nd edn vol III, Federation of American Societies for Experimental Biology. Bethesda, MD.

Bartholomew J W 1980 Stains for microorganisms in smears. In: Clark G (ed) Staining procedures, 4th edn, The Williams and Wilkins Co., Baltimore MD.

Berry L J, Smythe D S 1961 Effects of bacterial endotoxins on metabolism. IV. Renal function and adrenocortical activity as factors in the nitrogen excretion assay for endotoxin. Journal of Experimental Medicine 114:761-778.

Bowdre J H, Poole M D, Oliver, J D 1981 Edema and hemoconcentration in mice experimentally infected with Vibrio vulnificus. Infection and Immunity 32:1193-1199.

Brenden R A 1984 Comparative pathogenesis of experimental Aeromonas hydrophila infections in mice and goldfish. Ph.D. thesis, Illinois State University, Normal, IL.

Corrin B 1980 Lung pathology in septic shock. Journal of Clinical Pathology 33:891-894.

Deepe G S, Coonrod J D 1980 Fulminant wound infection with Aeromonas hydrophila. Southern Medical Journal 73:15461547.

Eddington C L, Kampschmidt R F 1968 Bilirubin production in endotoxin-treated or tumor-bearing rats. Proceedings of the Society for Experimental Biology and Medicine 129:580584.

Feaster F T, Nisbet R M, Barber J C 1978 Aeromonas hydrophila corneal ulcer. American Journal of Ophthalmology 85:114 117.

Filkins J P 1969 Hepatic vascular response to endotoxin. Proceedings of the Society for Experimental Biology and Medicine 131:1235-1238.

Hambleton P, Harris-Smith P W, Bailey, N E, Strange R E 1977 Changes in whole blood and serum components during Francisella tularensis and rabbit pox infections of rabbits. British Journal of Experimental Pathology 58:644-652.

Hardaway R M 1980 Endotoxaemic shock. Diseases of the Colon and Rectum 23:597-604.

Hazen T C, Fliermans C B, Hirsch R P, Esch G W 1978 Prevalence and distribution of Aeromonas hydrophila in the United States. Applied and Environmental Microbiology 36:731-738.

Huizinga H W, Esch G W, Hazen T C 1979 Histopathology of red-sore disease (Aeromonas hydrophila) in naturally and experimentally infected largemouth bass Micropterus salmoides (Lacepede). Journal of Fish Diseases 2:263-277.

Kabir S, Rosenstreich D L, Mergenhagen S E 1978 Bacterial endotoxins and cell membranes. In: Jeljaszewicz J, Wadstrom T (eds) Bacterial toxins and cell membranes, Academic Press, London, pp 59-87.
Ketover B P, Young L S, Armstrong D 1973 Septicemia due to Aeromonas hydrophila: clinical and immunologic aspects. Journal of Infectious Diseases 127:284-290.

Kirk R E 1968 Experimental design: procedures for the behavioral sciences. Brooks/Cole Publishing Co., Belmont, CA.

Levy E, Ruebner, B H 1967 Hepatic changes produced by a single dose of endotoxin in the mouse. Light microscopy and histochemistry. American Journal of Pathology 51:269285.

Ljungh A, Kronevi T 1982 Aeromonas hydrophila toxinsintestinal fluid accumulation and mucosal injury in animal models. Toxicon 20:397-407.

Luna L G 1968 Manual of histologic staining methods of the Armed Forces Institute of Pathology, 3rd edn. McGrawHill Book Co., New York.

MacIntyre S, Buckley J T 1978 Presence of glycerophospholipid: cholesterol acyltransferase and phospholipase in culture supernatant of Aeromonas hydrophila. Journal of Bacterio$\log y$ 135:402-407.

Ramsay A M, Rosenbaum B J, Yarbrough C L, Hotz J A 1978 Aeromonas hydrophila sepsis in a patient undergoing haemodialysis therapy. Journal of the American Medical Association 239:128-129.

Rigney M M, Zilinsky J W, Rouf M A 1978 Pathogenicity of Aeromonas hydrophila in red leg disease in frogs. Current Microbiology 1:175-179.

Roberts R J 1978 Fish pathology. Bailliere Tindall, London.

Shands J W, Miller V, Martin H 1969 The hypoglycemic activity of endotoxin. I. Occurrence in animals hyperreactive to endotoxin. Proceedings of the Society for Experimental Biology and Medicine 130:413-417.

Shotts E B, Gaines J L, Martin C, Prestwood A K 1972 Aeromonas-induced deaths among fish and reptiles in an eutrophic inland lake. Journal of the American Veterinary Medical Association 161:603-607.

Sirinavin S, Likitnukul L, Lolekha S 1984 Aeromonas septicaemia in infants and children. Pediatric Infectious Disease 3:122-125.

Thelestam M, Ljungh, A 1981 Membrane-damaging and cytotoxic effects on human fibroblasts of alpha- and betahaemolysins from Aeromonas hydrophila. Infection and Immunity 34:949-956.

Trust T J, Chipman D C 1979 Clinical involvement of Aeromonas hydrophila. Canadian Medical Association Journal 120:942946.

Walker R I, Chesbro W 1975 Klebsiella pneumonia and Staphylococcus aureus infections in mice: differences in uremia and ammoniagenesis. Infection and Immunity 12:571-575.

Wretlind B, Mollby R, Wadstrom T 1971 Separation of two hemolysins from Aeromonas hydrophila by isoelectric focusing. Infection and Immunity 4:503-505. 